\title{
STUDI KOMPARASI SUBJEK VASEKTOMI DAN NON VASEKTOMI TERHADAP KADAR ENDORPHIN DAN LIBIDO
}

\author{
Palupi Sesotyorini \\ Mahasiswa Magister Ilmu Kesehatan Reproduksi, Fakultas Kedokteran, \\ Universitas Airlangga Surabaya sesotyorinipalupi@gmail.com
}

\begin{abstract}
Abstrak
Masih banyak keraguan untuk mengikuti vasektomi di Indonesia. Penelitian efek vasektomi terhadap kadar endorphin dan kepuasan seksual menunjukkan hasil yang kontradiktif. $\beta$ endorphin yang diproduksi baik ditingkat pusat maupun ditingkat perifer, ikut berperan dalam steroidogenesis dan dalam modulasi kegiatan seksual. Namun perbedaan antara kadar endorphin sebagai salah satu parameter kepuasan seksual pada laki-laki vasektomi dan non vasektomi di Indonesia belum jelas. Penelitian ini dilakukan untuk membandingkan efek vasektomi dan non-vasektomi terhadap kadar endorphin, dan kepuasan seksual di Blitar, Indonesia. Desain penelitian menggunakan observasional analitik retrospektif kohort. Partisipan sebanyak 41 orang per kelompok (vasektomi dan non-vasektomi). Kelompok vasektomi adalah partisipan yang telah dilakukan vasektomi $\geq 2$ tahun. Serum partisipan diambil untuk diukur kadar endorphin secara ELISA. Kepuasan seksual diukur dengan Hypoactive Sexual Desire Disorder (HSDD) Screener untuk menilai libido. Hasil menunjukkan bahwa kadar endorphin, dan libido menunjukkan perbedaan tidak bermakna antara kelompok vasektomi dan nonvasektomi $(p=0.829 ; p=1,0)$. Berdasarkan hasil penelitian tersebut dapat disimpulkan bahwa tidak didapatkan perbedaan kadar endorphin dan libido antara partisipan yang telah vasektomi 2 tahun dengan patisipan yang tidak vasektomi. Hal tersebut dapat dipakai sebagai bahan pertimbangan bagi laki-laki memilih vasektomi dalam berkontrasepsi serta dapat dijadikan salah satu dasar penentuan kebijakan.
\end{abstract}

Kata kunci Vasektomi, endorphin, libido. 


\begin{abstract}
There are still many doubts about joining a vasectomy in Indonesia. Research on the effects of vasectomy on endorphin levels and sexual satisfaction showed contradictory results. $\beta$ endorphins, which are produced both at the central and peripheral levels, play a role in steroidogenesis and in modulation of sexual activity. However, the difference between endorphin levels as a parameter of sexual satisfaction in vasectomy and non vasectomy men in Indonesia is unclear. This study was conducted to compare the effects of vasectomy and non-vasectomy on endorphin levels, and sexual satisfaction in Blitar, Indonesia. The study design used a retrospective observational analytic cohort. Participants were 41 people per group (vasectomy and non-vasectomy). The vasectomy group is a participant who has had a vasectomy $\geq 2$ years. Serum participants were taken to measure endorphin levels by ELISA. Sexual satisfaction is measured by Hypoactive Sexual Desire Disorder (HSDD) Screener to assess libido. The results showed that the levels of endorphins, and libido showed no significant differences between the vasectomy and non-vasectomy groups $(p=0.829 ; p=1.0)$. Based on the results of these studies it can be concluded that there was no difference in levels of endorphin and libido between participants who had a 2-year vasectomy and those who did not have a vasectomy. This can be used as a consideration for men to choose vasectomy in contraception and can be used as a basis for determining policy.
\end{abstract}

Keywords Vasectomy, endorphin, libido. 


\section{PENDAHULUAN}

Ada beberapa metode KB untuk mengatasi ledakan penduduk, antara lain vasektomi, yang merupakan teknik operasi pada pria bertujuan untuk memutuskan kontinuitas transportasi sperma dari testis keluar (BKKBN, 2016). Vasektomi termasuk prosedur bedah urologi yang sering dilakukan di Amerika Serikat dengan kira-kira 526.501 orang telah menjalani vasektomi pada setiap tahunnya (Barone et al., 2006).

Keputusan untuk mengikuti vasektomi masih banyak menimbulkan keraguan bagi masyarakat Indonesia dengan alasan kekhawatiran kehilangan kejantanan, karena vasektomi masih sering disalah artikan dengan kebiri, sehingga menyebabkan rendahnya jumlah peserta $\mathrm{KB}$ vasektomi di Indonesia (BKKBN, 2017; Sutinah, 2017).

Sampai saat ini masih didapatkan banyak penelitian yang kontradiktif terhadap efek vasektomi dengan menggunakan subjek penelitian, objek penelitian, teknik vasektomi dan waktu observasi post vasektomi yang berbeda. Penelitian efek vasektomi terhadap kadar endorphin sebagai neurotransmiter oleh Paulson pada tahun 1989 pada pria infertil dibandingkan pria fertil, didapatkan hasil yang sama pada kedua kelompok. Hasil yang berbeda diperoleh dari penelitian oleh Shawky pada tahun 2006 didapatkan hasil kadar lebih rendah pada kelompok infertil.

Penelitian kontradiktif lain terhadap efek vasektomi juga dilakukan Peng et al. pada tahun 2008 yang melakukan observasi 10 hari post vasektomi terhadap efek kerusakan spermatogenik kelinci dewasa dengan teknik vasektomi open ended dibandingkan dengan teknik closed ended pada vas deferens pars inguinal, hasilnya tidak didapatkan efek kerusakan spermatogenik pada kedua teknik. Ma et al. pada tahun 2016 melakukan observasi 37 hari post vasektomi pada tikus dewasa dengan teknik ligasi ganda tanpa pemotongan vas deferens pars inguinal, didapatkan efek kerusakan spermatogenik. Hazal et al. tahun 2016 melakukan observasi
2 bulan post vasektomi tikus pre pubertas dibandingkan pubertas didapatkan hasil kerusakan spermatogenik. Wang et al. pada tahun 2008 melakukan observasi 3 bulan post vasektomi pada tikus dewasa dengan teknik vasektomi proksimal dibandingkan dengan vasektomi distal tidak didapatkan hasil kerusakan spermatogenik. Geierhaas et al. pada tahun 1991 melakukan observasi 9 bulan tikus dewasa didapatkan hasil selain spermatogenesis yang tidak terganggu, tidak ditemukan perbedaan kadar testosteron, FSH, dan LH pada serum pria setelah dilakukan vasektomi bila dibandingkan dengan yang tidak divasektomi, yang berarti menunjukkan bahwa fungsi testis tetap tidak berubah. Observasi pada pria dewasa yang dilakukan Mo et al. pada tahun 1995 terhadap testosteron pria post vasektomi sebelum dan sesudah 20 tahun, didapatkan hasil kadar testosteron lebih rendah pada kelompok post vasektomi sebelum 20 tahun.

Pengaruh vasektomi terhadap fungsi seksual yaitu pada kegairahan dan kepuasan seksual telah dilakukan oleh Perkumpulan Kontrasepsi Mantap Indonesia (PKMI, 2008) dan ditemukan dari 400 pria yang telah dilakukan vasektomi ternyata $50 \%$ menyatakan bertambah kegairahan bersenggama dengan istri, $40 \%$ menunjukkan tidak merasakan perubahan, $7 \%$ tidak memperhatikan dan $3 \%$ mengatakan menurun. Hal serupa dilakukan di Brazil menunjukkan bahwa vasektomi memberikan dampak positif pada fungsi seksual khususnya pada desire dan kepuasan seksual (Eduardo, 2005).

Dalam memenuhi fungsi seksual normal seorang pria, banyak faktor yang berpengaruh. Otak khususnya daerah hipotalamus dan cortex cerebri bertanggung jawab terhadap fungsi libido pria. $\beta$ endorphin sebagai opiat endogen diproduksi baik ditingkat pusat maupun ditingkat perifer misalnya pada sistem reproduksi. Setelah $\beta$ endorphin menempati reseptornya, akan berperan dalam steroidogenesis dan dalam modulasi kegiatan seksual (Campbell, 2016). Namun perbedaan antara kadar endorphin sebagai salah satu parameter 
kepuasan seksual pada laki-laki vasektomi dan non vasektomi di Indonesia belum jelas.

Berdasarkan uraian di atas, dilakukan penelitian untuk membuktikan tidak adanya perbedaan kadar endorphin serta fungsi seksual dalam hal libido antara subjek dengan status vasektomi dan non vasektomi. Kondisi subjek dengan status non vasektomi bertujuan untuk mewakili keadaan sebelum vasektomi. Kondisi ini diperlukan sebagai komparasi kondisi subjek dengan status vasektomi.

Cakupan vasektomi yang bertambah rendah diharapkan dapat diatasi dengan adanya pemahaman dan pengetahuan calon akseptor tentang vasektomi yang tercermin dalam Kebijakan Advokasi dan KIE (Komunikasi, Informasi dan Edukasi) Calon Akseptor oleh pemerintah melalui Badan Kependudukan dan Keluarga Berencana Nasional (BKKBN). Urgensi dari penelitian ini adalah untuk dijadikan salah satu dasar dalam menentukan kebijakan tersebut, baik kebijakan ditingkat provinsi maupun di tingkat Nasional. Selain itu hasil penelitian ini dapat dipakai sebagai bahan pertimbangan bagi laki-laki sebagai kepala keluarga dalam memilih vasektomi dalam berkontrasepsi sebelum Kebijakan Advokasi dan KIE (Komunikasi, Informasi dan Edukasi) Calon Akseptor dibuat.

\section{METODE PENELITIAN 2.1 Rancangan Penelitian}

Desain penelitian ini adalah observasional analitik dengan jenis penelitian retrospektif kohort.

Besar sampel menurut menurut Rosner 2015 ukuran minimum sampel untuk metode ini adalah 41 subjek dan menurut rumus untuk menentukan besar sampel penelitian adalah

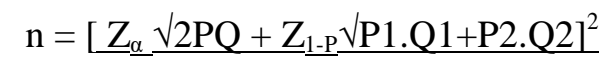

$$
[\mathrm{P} 1-\mathrm{P} 2]^{2}
$$

$$
\begin{array}{ll}
\mathrm{n} & =\text { besar sampel } \\
\mathrm{Z}_{1-\mathrm{P}} & =\text { deviat baku }=1,28 \\
\mathrm{Z} \alpha & =\text { deviat baku alpha }=1,96
\end{array}
$$

$$
\begin{array}{ll}
\mathrm{P} 1 & =\text { proporsi subjek vasektomi }(\%) \\
& =\text { vasektomi terhadap PUS } \\
\text { Q1 } & =95 \% \\
\mathrm{P} 2 & =\text { vasektomi dengan keluhan }(\%) \\
\mathrm{Q} 2 & =60 \% \\
\mathrm{Q} 1 & =1-\mathrm{P} 1 \\
\mathrm{Q} 2 & =1-\mathrm{P} 2
\end{array}
$$

Maka sampel minimal yang diambil adalah sebesar 41.

Sampel sebesar 41 orang pada masingmasing kelompok vasektomi 2 tahun sebelum waktu penelitian, dibandingkan dengan 41 orang kelompok kontrol untuk membandingkan kadar endorphin dan libido. Pada kelompok vasektomi dipilih waktu 2 tahun sebelumnya, dengan alasan segala bentuk hambatan dan efek samping yang kemungkinan timbul dianggap sudah hilang sama sekali.

\subsection{Tempat dan Waktu Penelitian}

Lokasi penelitian ini adalah Kota Blitar yang dipilih sebagai lokasi penelitian karena memiliki capaian vasektomi yang cukup tinggi dalam satu tahun, sehingga jangkauan pengambilan sampel menjadi lebih visibel dibandingkan dengan di tingkat kabupaten/kota lainnya. Selain itu, range akseptor usia muda lebih banyak dan penapisan sebelum pelayanan dipandang cukup baik. Pengambilan sampel dilakukan pada Bulan Oktober 2018.

\subsection{Variabel Penelitian}

Variabel pada penelitian ini terdiri dari varibel bebas dan variabel terikat. Variabel bebas yaitu vasektomi. Variabel terikat adalah endorphin dan libido.

\subsection{Definisi Operasional Variabel}

a. Kadar endorphin adalah kadar endorphin pada serum darah yang diambil IV pada subjek vasektomi dan non vasektomi yang diambil di pagi hari setelah istirahat \pm 30 menit dan diukur dengan metode ELISA.

b. Tingkat libido adalah jumlah kumulatif skor dorongan/kegairahan/keinginan 
seksual pada subjek vasektomi dan non vasektomi terhadap pasangannya yang diukur dengan HSDD Screener.

\subsection{Prosedur Penelitian}

Pembekalan diberikan kepada petugas dan subjek kedua kelompok termasuk pemberian informasi lengkap sampai penanda tanganan lembar persetujuan atau penolakan. Subjek dari masing-masing kelompok dihadirkan di waktu yang bersamaan, kemudian diberi nomor urut yang random, kode untuk masing-masing subjek diberikan oleh peneliti dan hanya diketahui oleh peneliti.

Bahan yang digunakan adalah $3 \mathrm{cc}$ darah vena diambil satu kali pada pagi hari (08.00-10.00) setelah istirahat sebelumnya, untuk mendapatkan serum, kemudian diperiksa kadar hormon endorphin pada masing- masing kelompok subjek menggunakan teknik ELISA. Pemeriksaan kadar endorphin dengan reagen Human $\beta$ EP (Beta-Endorphin) ELISA Kit merk elabsience.

Pengambilan sampel darah dilakukan setelah pengisian Hypoactive Sexual Desire Disorder (HSDD) Screener dengan wawancara oleh petugas yang telah dibekali. Hasil kuesioner diberi kode yang sama dengan hasil sampel darah. Pembacaan sampel dilakukan di Rumah Sakit Khusus Infeksi Universitas Airlangga.

\subsection{Pengolahan dan Analisis Data}

Fungsi seksual penderita di kaji dengan Hypoactive Sexual Desire Disorder (HSDD) Screener untuk mengetahui tingkat libido.

Serum hasil pemeriksaan di pisahkan dari sampel darah dengan sentrifuse 3000 rpm yang dilakukan di Puskemas Sanan Wetan Blitar. Setelah semua sampel terkumpul, dikemas dalam tempat, kemudian dibawa ke Laboratorium Rumah Sakit Khusus Infeksi Surabaya untuk dilakukan pembacaan hasil.

Kadar endhorpin dilakukan uji normalitas kemudian dilakukan uji beda dengan uji independent $\mathrm{T}$, sedangkan libido dilakukan uji beda dengan Mann-Whitney.
Data dijelaskan secara analisis menggunakan tabel yang diintepretasikan dalam bentuk narasi.

\subsection{Ethical Clearance}

Penelitian ini telah mendapatkan persetujuan dari Komite Etik Fakultas Kedokteran UNAIR.

\section{HASIL DAN PEMBAHASAN}

Karakteristik umum partisipan dapat dilihat pada tabel 3.1 berikut ini :

Tabel 3.1 Karakteristik Umum Partisipan

\begin{tabular}{|c|c|c|c|}
\hline & & $\begin{array}{c}\text { Vasek } \\
\text { tomi } \\
(n=41)\end{array}$ & $\begin{array}{c}\text { Non } \\
\text { Vasek } \\
\text { tomi } \\
(\mathrm{n}=41)\end{array}$ \\
\hline \multirow{4}{*}{$\begin{array}{l}\text { Umur } \\
\text { (Tahun) }\end{array}$} & Mean & 43,83 & 40,98 \\
\hline & $\begin{array}{l}\text { Standart } \\
\text { Dev }\end{array}$ & 4,35 & 6,35 \\
\hline & Min & 33 & 26 \\
\hline & Max & 50 & 50 \\
\hline \multirow{5}{*}{$\begin{array}{l}\text { Pendidik } \\
\text { an }\end{array}$} & SD & 5 & 2 \\
\hline & SMP & 7 & 6 \\
\hline & SMA & 28 & 27 \\
\hline & S1 & 1 & 5 \\
\hline & S2 & & 1 \\
\hline
\end{tabular}

Dari hasil anamnesis pada kedua kelompok vasektomi dan non vasektomi, tidak didapatkan subjek dengan jumlah istri lebih dari satu, tidak didapatkan subjek yang menderita diabetes, stroke, gagal ginjal, jantung, pembesaran kelenjar tiroid, anemia,dan ikterik. Tidak didapatkan subjek dengan riwayat pengobatan obat hipertensi, hormon estrogen, anti depresan, dan tranquillizer. Tidak didapatkan subjek yang mengalami kegagalan dan komplikasi pada kelompok vasektomi.

\subsection{Kadar Endorphin}

Kadar endorphin pada kedua kelompok subjek tertuang dalam tabel 3.2 berikut : 
Tabel 3.2 Distribusi kadar endorphin kelompok subjek vasektomi dan non vasektomi

\begin{tabular}{|c|c|c|}
\hline \multirow[t]{2}{*}{ Nilai } & \multicolumn{2}{|c|}{ Kelompok } \\
\hline & Vasektomi & Non Vasektomi \\
\hline Mean & 108,2193 & 110,2780 \\
\hline Median & 98,9920 & 108,9310 \\
\hline Minimal & 52,20 & 64,38 \\
\hline Maksimal & 194,63 & 192,27 \\
\hline Total & 41 & 41 \\
\hline $\mathbf{P}$ & & 0,828 \\
\hline
\end{tabular}

Hasil statistik menunjukkan $\mathrm{p}=0.829$, berarti tidak didapatkan perbedaan antara kedua kelompok subjek vasektomi dan non vasektomi.

Endorphin adalah neuropeptida opioid endogen dan hormon peptida pada manusia dan hewan lainnya yang diproduksi oleh sistem saraf pusat dan kelenjar pituitari. Istilah "endorphin" menyiratkan aktivitas farmakologis (serupa dengan aktivitas kategori biokimia kortikosteroid) dibandingkan dengan formulasi kimia tertentu. Endorphin terdiri dari dua bagian: endo- dan -morphin merupakan bentuk pendek dari kata-kata endogen dan morfin, yang berarti zat seperti morfin yang berasal dari dalam tubuh. Kelas endorphin mencakup tiga senyawa $\alpha$-endorphin, $\beta$ endorphin, dan $\gamma$-endorphin yang secara khusus mengikat reseptor $\mu$-opioid ( $\mathrm{Li} \mathrm{Y}$ et al., 2012).

Endorphin adalah neuropeptida opioid endogen yang dapat menghasilkan perasaan euforia sangat mirip dengan yang dihasilkan oleh opioid lainnya.

Endorphin mengikat reseptor opioid pada neuron, menghambat pelepasan neurotransmitter dan mempengaruhi transmisi dari impuls ke otak dan dapat mengurangi depresi (Adam et al., 2010).

Modulasi endorphin bersama sistem endokrin reproduksi berperan pada semua level aksis hypothalamo-pituitary-gonadal terutama melalui modulasi sekresi GnRH dan LH (Gore et al., 2001). $\beta$-endorphin memiliki baik efek inhibisi atau excitatory pada aktifitas seksual. Selain itu endorphin juga berpengaruh secara lokal pada jaringan reproduksi (Staszkiewicz, 2007).

Endorphin dan reseptor endorphin (mu, delta-dan kappa-) ditemukan pada setiap tipe sel spermatozoa dalam tubulus seminiferus tikus, menunjukkan bahwa endorphin memiliki peran dalam proses spermatogenesis baik sebagai inhibitor pada jangka pendek maupun sebagai modulator pada jangka panjang (Haizea, 2016). Endorphin kemungkinan berpartisipasi dalam regulasi fungsi reproduksi laki-laki (Subiran et al., 2011). Reseptor opioid berfungsi secara fungsional, dengan respon tergantung waktu (Haizea et al., 2016) dan musim (Madani, 2016).

Fungsi utama endorphin adalah untuk menghambat transmisi sinyal nyeri; mungkin juga menghasilkan perasaan euforia yang sangat mirip dengan yang dihasilkan oleh opioid lainnya. Endorphin dalam tubuh bisa dipicu munculnya melalui berbagai kegiatan, seperti pernapasan yang dalam, relaksasi, serta meditasi. Endorphin dianggap sebagai zat penghilang rasa sakit yang terbaik karena diproduksi oleh tubuh manusia sendiri.

Beberapa mekanisme lain yang mungkin dapat menginduksi $\beta$ endorphin dalam sirkulasi darah yaitu analgesia, asam laktat yang berlebih, dan faktor metabolik (Adam et al., 2010). Endorphin dilepaskan dengan cara yang bervariasi tergantung masing-masing individu. Beberapa makanan seperti coklat atau lada dapat memicu sekresi endorphin. Endorphin mengikat reseptor opioid pada neuron, menghambat pelepasan neurotransmitter dan mempengaruhi transmisi dari impuls nyeri ke otak dan dapat mengurangi tingkat kecemasan dan depresi (Adam et al., 2010).

Endorphin atau opiat endogen merupakan kunci utama dalam memediasi keterikatan seseorang dengan orang lain dan juga berperan dalam perbaikan depresi. Sistem opiat berkaitan dengan mood dan depresi. Aktivitas fisik menambah sekresi opioid endogen pada otak yang berfungsi dalam munculnya rasa euforia dan pengurangan nyeri. Sistem penekanan nyeri ini diaktifkan dengan merangsang daerah reseptor endorphin di zat kelabu 
periaqueduktus otak tengah. Pemberian stimulasi dapat merangsang reseptor syaraf asenden, dimana rangsangan tersebut akan dikirim ke hipotalamus dengan perjalanan melalui spinal cord, diteruskan ke bagian pons dilanjutkan ke bagian kelabu pada otak tengah (periaqueduktus), rangsangan yang diterima oleh periaqueduktus ini disampaikan kepada hipotalamus, dari hipotalamus inilah melalui alur saraf desenden hormon endorphin dikeluarkan ke pembuluh darah (Adam et al., 2010).

Modulasi endorphin bersama sistem endokrin reproduksi berperan pada semua level aksis hypothalamo-pituitary-gonadal terutama melalui modulasi sekresi GnRH dan LH (Gore et al., 2001). $\beta$-endorphin memiliki baik efek inhibisi atau excitatory pada aktifitas seksual. Selain itu endorphin juga berpengaruh secara lokal pada jaringan reproduksi (Staszkiewicz, 2007) terbukti dengan ditemukannya gen pengkode prekusor endorphin pada jaringan reproduksi yang mengatur stimulasi steroidogenesis secara autokrin maupun parakrin pada sel luteal sapi (Varsono, 1990) menyebabkan terjadinya perubahan respon sel intertitial terhadap LH (Gore et al., 2001).

\subsection{Libido}

Pengukuran libido dengan pengisian kuesioner HSD pada masing-masing kelompok subjek. Hasil dikategorikan kedalam skor jika $\geq 7$ libido $\downarrow$ dan jika $<7$ libido Normal.

Didapatkan hasil tertuang dalam tabel 3.3 berikut :

Tabel 3.3 Distribusi libido partisipan kelompok vasektomi dan non vasektomi

\begin{tabular}{cccc}
\hline Kelompok & $\begin{array}{c}\text { Libi } \\
\text { do } \downarrow\end{array}$ & $\begin{array}{c}\text { Libido } \\
\text { Normal }\end{array}$ & Total \\
\hline Vasektomi & 4 & 37 & 41 \\
\hline NonVasektomi & 4 & 37 & 41 \\
\hline
\end{tabular}

Uji statistik menunjukkan hasil $\mathrm{p}=1,0$ tidak ada perbedaan dalam hal libido antara kelompok partisipan vasektomi dan nonvasektomi.

Vasektomi adalah prosedur untuk menghentikan kapasitas reproduksi pria dengan jalan melakukan oklusi vas deferen tanpa mempengaruhi fungsi dari kelenjarkelenjar asesoris sehingga produksi cairan semen tetap berlangsung dan pria yang divasektomi tetap berejakulasi namun ejakulatnya tidak mengandung sel spermatozoa.

Vasektomi dapat dilakukan dengan anestesi lokal yang dapat di kerjakan di klinik, tidak perlu menggunakan anestesi umum.

Efektifitas vasektomi dapat dilihat dari tidak adanya jumlah sperma pada hasil pemeriksaan analisa sperma sebagai efektifitas kontrasepsi atau dengan tidak terjadinya kehamilan sebagai tanda efektifitas tindakan oklusi (David, 2009).

Resiko terjadinya kehamilan diperkirakan sekitar 1 per 1.000 tindakan dengan setengah dari kehamilan terjadi pada 3 bulan awal setelah tindakan vasektomi (Deneux and Tharaux, 2004).

Secara harfiah istilah vasektomi berarti pemotongan vas deferens sepanjang 1-2 cm, disertai pengikatan pada masing-masing ujung potongan yang tertinggal. Vas deferens adalah saluran yang menyalurkan spermatozoa dari testis keluar. Dengan demikian terjadi hambatan penyaluran spermatozoa melalui vas deferens.

Vas deferens bersama pembuluh darah dan syaraf membentuk suatu berkas yang dibungkus oleh fascia spermatika eksterna dan dikenal sebagai funikulus spermatikus. Secara topografis, vas deferens membentang mulai dari dalam rongga abdominal, melalui annulus inguinalis internus masuk kedalam kanalis inguinalis dan keluar melalui annulus inguinalis eksternus masuk kedalam skrotum.

Pada proses vasektomi, untuk mencapai vas deferens pars skrotalis, skrotum dan fascia spermatika harus dibuka, pembukaan ini dilakukan dengan melakukan insisi atau diseksi dengan pembiusan lokal. Setelah vas deferens dicapai, maka dilakukan pemotongan sepanjang 1-2 $\mathrm{cm}$ dan 
penyumbatan ujung-ujung potongan bisa dilakukan dengan ikatan benang sutra atau kauter listrik.

Berdasarkan pada cara membuka kulit untuk mencapai vas deferens maka dibedakan antara vasektomi konvensional dengan vasektomi tanpa pisau. Setelah akses ke vas deferens tercapai, metode penyumbatan yang dilakukan pada intinya sama saja, perbedaan hanya pada penutupan kulit, dapat dilakukan dengan penjahitan atau tanpa jahitan.

Vas deferens merupakan organ berbentuk tabung yang berasal dari mesonephric (wolffian). Pada manusia, vas deferens panjangnya 30 sampai $35 \mathrm{~cm}$, dimulai pada cauda epididimis dan berakhir dalam duktus ejakulasi, terletak medial terhadap vesikula seminalis dan posterior prostat. Secara klasik terbagi menjadi lima bagian: (1) segmen yang terdapat di dalam tunika vaginalis, (2) segmen skrotalis, (3) segmen inguinal, (4) retroperitoneal atau bagian pelvis, dan (5) ampula vas deferen (Campbell, 2016).

Pars skrotalis merupakan bagian yang dipotong dan diligasi saat vasektomi. Duktus deferens terdiri atas otot polos yang mendapatkan persarafan dari system simpatik, sehingga dapat berkontraksi untuk menyalurkan sperma dari epididimis ke uretra posterior.

Jaringan adventisia yang menyelubungi vas deferens bagian luar terdiri dari pembuluh darah dan saraf kecil. Sedangkan dinding tebal vas deferens dibentuk oleh beberapa lapis otot polos, lapisan longitudinal dalam dan luar, lapisan melingkar tengah dan lapisan epitel kolumnar pseudostratified dengan stereocilia nonmotile sebagai lapisan dalam, yang dikenal sebagai mukosanya. Ketiga lapisan otot polos ini diinervasi saraf adrenergik yang terbanyak ditemukan di lapisan luar. Vas deferens menerima persarafan dari sistem saraf simpatik dan parasimpatis yang berasal dari saraf hipogastrik yang mengalir melalui saraf presacral. Kerjasama otot dan saraf pada vas deferen berfungsi dalam transportasi sperma dan ejakulasi (Campbell, 2016).
Transport sperma melalui vas deferens dipengaruhi oleh beberapa proses fisiologis. Pertama, vas deferens manusia menunjukkan motilitas spontan. Juga memiliki kapasitas untuk merespon saat diregangkan. Akhirnya, cairan dalam vas deferens dapat didorong ke dalam uretra oleh kontraksi peristaltik yang kuat timbul baik oleh stimulasi listrik dari saraf hipogastrik atau dari neurotransmitter adrenergik. Ini menunjukkan bahwa segera sebelum emisi, dengan stimulasi simpatik, sperma segera diangkut dari distal epididimis melalui vas deferens ke duktus ejakulasi. Transport yang cepat ini konsisten dalam vas deferens yang memiliki rasio otot-terhadap-lumen tertinggi (sekitar 10:1) dibandingkan organ berongga lain dalam tubuh (Campbell, 2016).

Cadangan sperma di vas deferens telah diperkirakan sekitar 130 juta, menunjukkan bahwa sperma ejakulasi manusia yang tersimpan dalam vas deferens memiliki proporsi yang signifikan dan akan dialirkan keluar setelah ada rangsangan seksual.

Vas deferens terlibat dalam pembersihan sperma yang berlebihan dari epididimis karena adanya kemampuan spermiophagy yang dimilikinya seperti telah diamati dibawah mikroskop elektron pada manusia dan kera. Pada kelinci, saat istirahat seksual, sperma epididimis diangkut melalui vas deferens dan bocor ke dalam uretra dalam jumlah kecil.

Berdasarkan cytoarchitecturenya selain sebagai transpot sperma, vas deferens manusia mungkin memiliki baik fungsi absorpsi dan sekresi. Sel utama vas deferens adalah sel khas yang mensintesis dan mensekresikan glikoprotein. Stereocilia, apikal blebbing, dan lisosom primer dan sekunder di dalam sel utama juga merupakan ciri khas sel yang terlibat dalam fungsi penyerapan. Fungsi vas deferens normal mungkin androgen dependent karena vas deferens secara aktif mengkonversi testosteron menjadi DHT. Dapat disimpulkan vas deferens bukan hanya saluran otot sederhana untuk sperma karena termasuk organ reproduksi yang kompleks.

Dorongan/kegairahan seksual merupakan kekuatan psikologis yang 
terbentuk dari lingkungan dan kondisi (Stoléru et al., 2014). Pusat pengaturan perilaku seksual di dalam otak sebagai organ seksual yang paling besar. Pada otak terdapat dua area terpisah yang paling bertanggung jawab terhadap perasaan seksual yaitu hypothalamus dan cortex cerebri, oleh karena itu perasaan seksual mula-mula ditimbulkan dalam otak.

Hypothalamus adalah merupakan bagian utama dari sistem limbik yang berfungsi mengatur tingkah laku emosional dan dorongan motivasional termasuk mengatur kondisi internal tubuh salah satunya dorongan untuk aktivitas seksual. Rangsangan pada beberapa area hypothalamus, khususnya pada sebagian besar hypothalamus anterior dan posterior akan menimbulkan dorongan seksual atau libido. Sedangkan cortex cerebri yang terletak pada bagian depan otak akan merekam segala informasi yang telah dipelajari, atau dari pengalaman yang didapat. Hal ini akan membantu dalam menentukan bagaimana berfikir, berperasaan, dan berperilaku tentang seks. Di dalam otak bagian ini pula yang menyebabkan kesadaran akan adanya rangsangan seksual. Cortex cerebri mengelola dorongan seksual dengan memproses informasi seksual, membuat keputusan seksual, mengingat kembali memori seksual, mengembangkan fantasi seksual, dan mempertimbangkan resiko seksual. Semua itu akan membentuk sikap mental, perasaan dan perilaku seksual (Stoléru et al., 2014).

Libido dapat dipengaruhi dengan cara hormonal yang erat kaitannya dengan androgen ataupun secara non-hormonal yang lebih terkait dengan faktor eksternal. Dari faktor hormonal selain karena menurunnya kadar hormon testosteron sebagai faktor fisik, menurunnya libido dapat juga disebabkan menurunnya kadar hormon tiroid, meningkatnya hormon prolaktin, kelelahan karena penyakit kronis, obatobatan dan juga bisa diakibatkan faktor psikologi seperti rasa bersalah, stres berkepanjangan dan pengalaman seksual yang tidak menyenangkan (Kandeel, 2001; Tjokronegoro, 2003). Kondisi psikologis seperti kecemasan, jenuh, ketakutan yang terus menerus dan depresi serta keadaan yang tidak sesuai dengan harapan dapat menekan dan menghambat dorongan seksual dengan berkurangnya sirkulasi testosteron (Pangkahila, 2005).

Master dan Johnson membagi dua faktor penyebab rendahnya dorongan seksual ini yaitu pertama faktor individu berupa akibat masalah organik seperti penyalahgunaan obat dan alkohol, kondisi sakit kronis tetapi lebih banyak faktor yang bersifat psikologis seperti ketakutan, depresi, cemas dan traumatik masa lalu. Kedua adalah faktor hubungan dengan pasangan seperti penolakan seksual sehinga menimbulkan rasa tidak dicintai atau ditolak, hilangnya ketertarikan atau daya tarik pada pasangan misalnya karena obesitas, hilangnya ketertarikan pasangan terhadap seks, masalah komunikasi (Balles, 2006). Faktor usia juga dapat mempengaruhi libido, dengan meningkatnya usia terjadi penurunan kadar testosteron sehingga diduga pula bahwa dorongan seksual akan terpengaruh (Baziad, 2003).

Kadar hormon testosteron diotak memiliki korelasi positif antara dengan libido, ketertarikan seksual dan aktivitas seksual. Kadar testosteron yang cukup di area libido otak berperan dalam timbulnya libido dan penyampaian rangsangan saraf aferen terhadap ereksi. (Nieschlag, 2000).

Hasil penelitian kali ini, tidak didapatkan perbedaan libido pada kelompok subjek vasektomi jika dibandingkan dengan kelompok subjek non vasektomi, hal ini serupa dengan hasil penelitian oleh Tobias tahun 2017 yang melakukan penelitian pada 90 orang post vasektomi dengan rentang waktu 3 bulan sampai 2,5 tahun sebelum penelitian dibandingkan 109 orang non vasektomi, didapatkan hasil tidak ada perbedaan kepuasan seksual baik dari pihak pria maupun wanita pada kelompok vasektomi dibandingkan kelompok non vasektomi.

Hubungan libido dan kadar testosteron serum merupakan hal yang kompleks. Pria dengan kadar tetosteron serum normal dapat 
juga mengalami penurunan libido dan pria dengan kadar subnormal dapat mempunyai libido yang normal.

Tindakan oklusi vas deferens pars skrotalis pada vasektomi dengan pemotongan dan ligasi, menyebabkan jalur transportasi sperma terhambat dan proses fertilisasi penyatuan dengan ovum tidak terjadi. Setelah operasi minor ini, spermatozoa akan terbendung pada ujung vas deferens sisi testis yang telah disumbat. Keberhasilan tindakan vasektomi ditentukan oleh banyak hal, termasuk didalamnya usia, waktu pelaksanaan dan ada tidaknya penyakit penyerta.

Keadaan azosperma setelah tindakan vasektomi akan meningkatkan self off assurance terhadap ketidak terjadinya kehamilan setelah berhubungan seksual pada pasangan (Eduardo, 2005). Hal ini akan menurunkan kadar Corticotropin Releasing Factor (CRF) baik di level pusat maupun dilevel perifer termasuk di level organ reproduksi pria yaitu epididimis, vas deferens, dan sel leydig testis. Sehingga tidak terjadi rangsangan terhadap produksi $\beta$ -endorphin (Shawky et al., 2006).

Modulasi endorphin bersama sistem endokrin reproduksi berperan pada semua level aksis hypothalamo-pituitary-gonadal terutama melalui modulasi sekresi GnRH dan LH (Gore et al., 2001) mengatur stimulasi steroidogenesis (Varsono, 1990; Gore et al., 2001) dan spermatogenesis baik sebagai inhibitor pada jangka pendek maupun sebagai modulator pada jangka panjang (Haizea, 2016).

Proses steroidogenesis akan menghasilkan testosteron yaitu hormon seks pria yang disekresikan oleh sel Leydig testis dan adrenal. Kolesterol sebagai bahan dasar untuk biosintesis testosteron berasal dari plasma darah dalam bentuk LDL melalui penangkapan kolesterol LDL oleh reseptor pada permukaan sel Leydig dan sebagian disintesis di dalam sel Leydig. Spermatogenesis pada tubulus seminiferus selama masa seksual aktif akibat stimulasi oleh hormon gonadotropin FSH yang dihasilkan di hipofisis anterior.
Pada keadaan post vasektomi, efek kerusakan spermatogenik yang terjadi akan berangsur menghilang dengan bertambahnya waktu. Hal ini disebabkan adanya kemampuan spermiophagy sel epididimis dan vas deferens dalam pembersihan sperma yang berlebihan (Campbell, 2016).

Kadar hormon testosteron diotak memiliki korelasi positif antara dengan libido, ketertarikan seksual dan aktivitas seksual di mana kadar testosteron yang adekuat menyebabkan perasaan aktif pada tubuh dan jiwa, siaga dan bersemangat, kesegaran umum (general mood), rasa kepercayaan diri, libido, serta aktivitas seksual, sebaliknya kadar testosteron inadekuat menyebabkan ketidakaktifan, letargi dan mood yang tertekan (Nieschlag, 2000). 


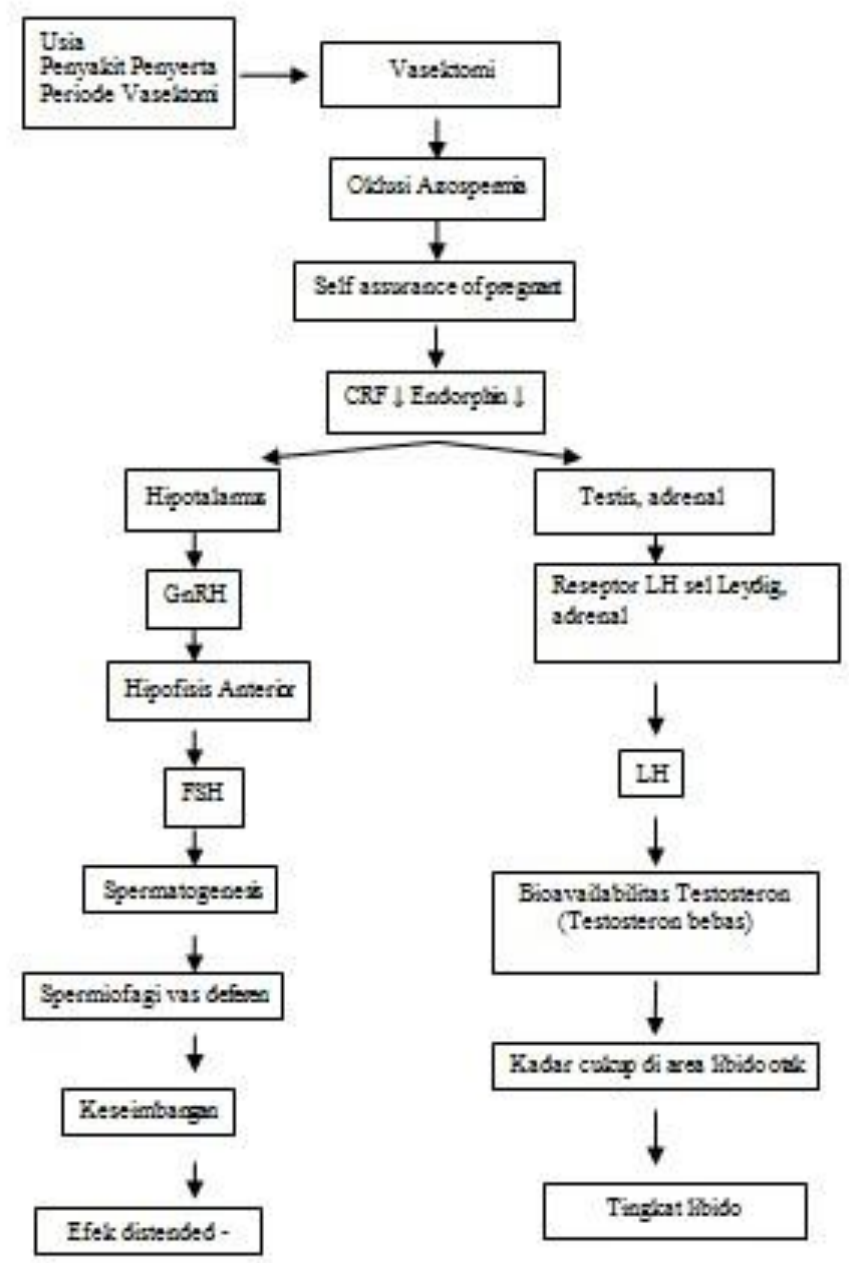

Gambar 3.1 Skema efek vasektomi terhadap kadar endorphin dan libido

\section{KESIMPULAN}

\subsection{Kesimpulan}

Berdasarkan hasil penelitian kadar endorphin dan libido pada kelompok post vasektomi 2 tahun dibandingkan dengan kelompok vasektomi dengan batasan usia 30-50 tahun, dapat disimpulkan tidak ada perbedaan kadar endorphin dan libido pada subjek status vasektomi dibandingkan dengan subjek status non vasektomi.

\subsection{Saran}

Berdasarkan pembuktian penelitian ini, masih diperlukan penelitian dengan menggunakan parameter lain misalnya kadar Nitric Oxide dan Acetylcholine sehingga dapat lebih meyakinkan hipotesis yang telah ada. Apabila dilakukan penelitian yang serupa, maka sebaiknya dilakukan pula pemeriksaan laboratorium yang mendukung hasil anamnesa penyakit terdahulu, agar dapat benar-benar dipastikan tidak terdapat penyakit yang dapat mempengaruhi terhadap hasil penelitian. Pihak istri dapat dilibatkan untuk dinilai juga kepuasan seksual dari sisi wanita. Agar hasil penelitian ini dapat 
disosialisasikan kepada pembuat kebijakan agar infornasi tentang keamanan vasektomi dapat tersampaikan kepada masyarakat, khususnya kepada pasangan usia subur yang sudah tidak ingin punya anak lagi.

\section{UCAPAN TERIMA KASIH}

Penulis mengucapkan terima kasih kepada Prof. Dr. Doddy M. Soebadi, dr.,Sp.B, Sp.U (K), Dr. H. Budi Utomo, dr., MS, Dr. Hermanto Tri Joewono, dr., Sp.OG (K), Dr. Lilik Herawati, dr., M.Kes., AIF dan Dr. Rina Yudiwati, dr., MS selaku pembimbing dan penguji dalam penelitian ini. Responden yang berpartisipasi dalam penelitian ini. Keluarga penulis, suami dr. Lila Tri Harjana, Sp. An, anak Rahmaniya Ardiyanti Harjana dan Rahmandio Adli Harjana yang telah memberikan dukungan moril untuk selalu memacu semangat belajar.

\section{DAFTAR PUSTAKA}

Alan, J., et al., 2016. Campbell-Walsh Urology 11th Ed. Philadelphia. Elsevier, Inc.

Balleshdads 29fertthncidited Sex4al sepeeihs9: Retrieved from : URL : http://ShandsHealthCare_inhibitedsexu alde: ire.html, on 30th Jan 2018.

Baziad, A., 2003. Menopause Dan Andropause. Jakarta : Yayasan Bina Pustaka Sarwono Prawirohardjo. p1969, 218-20.

Bertero, E., et al., 2005. Assessment Of Sexual Function In Patients Undergoing Vasectomy Using The International Index Of Erectile Function. Int. braz $j$ urol. 31(5). ISSN 1677-6119.

El-Haggar, S., et al., 2006. Beta-endorphin In Serum And Seminal Plasma In Infertile Men. Asian J Androl. 8 (5)

Ganong, W.F., et al., 2008. Buku Ajar Fisiologi Kedokteran Edisi 22. Jakarta: EGC.

González-Sales, M., et al., 2016. Modeling Testosterone Circadian Rhythm In Hypogonadal Males: Effect of Age and
Circannual Variations. The AAPS Journal. 18(1): 217-227.

Guyton, A., et al., 2007. Buku Ajar Fisiologi Kedokteran. Penerbit Buku Kedokteran. Jakarta

Haizea, 2016. Expression And Localization Of Opioid Receptors In Male Germ Cells And The Implication For Mouse Spermatogenesis. Retrieved from https://doi.org/10.1371/journal.pone/.01 52162., on 6th Feb 2018

Madani, S., et al., 2016. Testosterone Effect On Testicular $\beta$-endorphin Expression In Sand Rat Psammomys Obesus. Annales D'Endocrinologie. Elseivere. 77(4). p.455.

Pangkahila, W., 2005. Menguak Disfungsi Ereksi : Menyimak masalah Pria, Keluhan Wanita. Jakarta : PT Gramedia. p 5-0,25-9,68.

Sprouse-Blum, A.S. et al., 2010. Understanding Endorphins And Their Importance In Pain Management. Hawaii Med J. 69(3): 70-71.

Sutinah. 2017. Partisipasi Laki-laki Dalam Program Keluarga Berencana Di Era Masyarakat Postmodern. Masyarakat, Kebudayaan dan Politik Vol. 30(3), hal. 289-299.

Van Anders, S.M., et al., 2007. Multiple Partners Are Associated With Higher Testosterone In North American Men And Women. Hormones and Behavior. 51: 454-459. Retrieved from doi:10.1016/j.yhbeh.2007.01.002. PMID 17316638., on 6th Feb 2018. 